\title{
LA ACCIÓN DE CUMPLIMIENTO COMO ACCIÓN TUTELAR*
}

\author{
BORIS ARIAS LÓPEZ
}

Para alcanzar a un Estado de Derecho no es suficiente la validez de las normas jurídicas sino que es indispensable su eficacia; en este sentido, en Bolivia desde la colonia existía el dicho de "la ley se acata pero no se cumple", lo que revelaba la brecha existente entre lo que la norma disponía y la falta de su realización. El presente trabajo se refiere a la acción de cumplimiento -su configuración y características- introducida por el legislador constituyente el año 2009 para hacer efectivo el contenido de la Constitución y las leyes.

\section{ANTECEDENTES DE LA ACCIÓN DE CUMPLIMIENTO BOLIVIANA}

En Bolivia, la acción de cumplimiento se constituye en una acción de defensa constitucional ${ }^{1}$ prevista por el art. 134 de la CPE, cuya finalidad es el resguardo de la eficiencia y efectividad del ordenamiento jurídico respecto de normas constitucionales y de orden legal de carácter operativo, sean incondicionales o con condición cumplida, plazo vencido o de vencimiento inminente, que en relación a los derechos puede tutelarlos de manera directa e indirecta en su dimensión objetiva y de manera indirecta en su dimensión subjetiva. En este sentido, su configuración responde a la de una "acción" ${ }^{2}$ entendida en su sentido amplio como la facultad de toda persona natural o jurídica, nacional o extranjera para acceder a un órgano jurisdiccional sin la necesidad de acreditar un perjuicio por el incumplimiento de la norma, ello debido a que el propósito de la acción de cumplimiento es la de efectivizar el ordenamiento constitucional y legal lo que per se constituye en un valor que hace a la pacífica y ordenada convivencia humana de forma que el estado de derecho no sea meramente retórico o declarativo.

\footnotetext{
*Colaboración recibida el 10 de febrero y aprobada el 09 de octubre de 2013.

** Magíster en Derecho Constitucional (Universidad Andina Simón Bolívar) y redactando tesis de Doctorado en Derecho Constitucional (Universidad Mayor de San Andrés). Letrado del Tribunal constitucional Plurinacional de Bolivia. Correo electrónico: borisito55@hotmail.com.

${ }^{1}$ La acción de cumplimiento se encuentra ubicada en el Capítulo Segundo del Título IV de la Primera Parte de la Constitución titulado "acciones de defensa".

2 El término "acción" constitucional se contrapone al término de "recurso" utilizado por la Constitución de 1967.
} 
En este sentido, José Antonio Rivera Santivañez sostiene que: "se puede señalar que la Acción de Cumplimiento es un proceso constitucional que tiene por objeto hacer cumplir, por la autoridad pública, un mandato imperativo impuesto por el ordenamiento jurídico, en aquellos casos en los que de manera injustificada incumple o se resiste a cumplirlo" ${ }^{\prime 3}$, mientras que Horacio Andaluz Vegacenteno sostiene que es la: "...acción instaurada para defender los mandatos claros y expresos de la Constitución, la demanda de cumplimiento de una ley no puede sino estar atada a dichos mandatos. Por tanto, al exigirse el cumplimiento de dicha ley se está exigiendo el cumplimento, por devolución, de la disposición constitucional que ordenó tal remisión legislativa" ${ }^{4}$ y tiene como antecedentes en el derecho comparado a:

- El Writ of Mandamus o mandamiento de ejecución, que en el derecho norteamericano constituye una orden judicial a funcionarios públicos para que desplieguen una determinada conducta, en contraposición al Writ of Injuntion que prohíbe a las autoridades la realización de actos lesivos a los derechos o intereses de los ciudadanos.

- El Mandado de Injunção, que en el Brasil procede ante la falta de normativa reglamentaria que impida ejercer derechos constitucionales.

- La acción de cumplimiento del art. 87 de la Constitución de Colombia, que establece que: "toda persona podrá acudir ante la autoridad judicial para hacer efectivo el cumplimiento de una ley o un acto administrativo. En caso de prosperar la acción, la sentencia ordenará a la autoridad renuente el cumplimiento del deber omitido", competencia de los juzgados contencioso-administrativos cuya resolución es impugnable ante el Concejo de Estado conforme la Ley № 393 de 1997.

- La acción de cumplimiento para controlar la inactividad administrativa prevista por el art. 200-6º de la Constitución del Perú que establece que: “...procede contra cualquier autoridad o funcionario renuente a acatar una norma legal o un acto administrativo, sin perjuicio de las responsabilidades de ley".

\section{El CUMPLIMIENTO DE LA NORMATIVA COMO CONDICIÓN DE UN} ESTADO DE DERECHO Y FUNDAMENTO DE LA ACCIÓN DE CUMPLIMIENTO

El intento histórico de mejoramiento y perfeccionamiento del "estado de derecho" en Bolivia se tradujo en la complejización de su cualificación, incluyendo a lo largo del tiempo a lo social (igualdad material y no mera igualdad

\footnotetext{
3 Rivera SAntiváñez, José Antonio, Jurisdicción constitucional-procesos constitucionales en Bolivia, Grupo Editorial Kipus, Tercera edición, 2011, p. 457.

${ }^{4}$ Andaluz Vegacenteno, Horacio, "El objeto de la pretensión en la acción de cumplimiento", La Gaceta Jurídica, La Nación. En: http://www.la-razon.com/suplementos/la_gaceta_juridica/objeto-pretensionaccion-cumplimiento_0_1576642407.html [visitado el 29/09/2013].
} 
formal de los ciudadanos mediante el establecimiento de condiciones mínimas de educación, de salud, de trabajo, etc.), a lo democrático (legitimadora de los actos y decisiones estatales mediante la participación ciudadana), y ahora a lo plurinacional comunitario (reconocimiento de una realidad ya existente que se pretende encausar a partir de lo estatal), elementos acumulativos pero no excluyentes que no implican que el Estado boliviano haya dejado de configurarse en un estado de derecho, más precisamente en un "estado unitario social de derecho plurinacional comunitario" (art. $1^{\circ}$ de la CPE).

El concepto de estado de derecho implica la subordinación del poder político y militar del Estado al ordenamiento jurídico; de forma que el derecho se constituye en el ámbito de validez del Estado y, por ende, en su límite (Hans Kelsen), encontrándose entre sus condiciones a las siguientes:

- Imperio de la ley, que implica que tanto gobernados y, sobre todo, gobernantes para evitar la arbitrariedad se someten a la ley; de tal forma, que a decir de Aristóteles: "...gobiernan las leyes y no los hombres...". Pese a ello, debe tenerse en cuenta que el imperio de la "ley" en un estado comunitario y autonómico como el nuestro se ha relativizado, debiéndose hablar más propiamente de la vigencia de la "norma", pues la ley ha dejado de ser el elemento normativo exclusivo y central que rige la conducta de gobernantes y gobernados ${ }^{5}$.

- Vigencia de derechos y garantías ${ }^{6}$, al respecto se debe indicar que mientras el ciudadano en resguardo de su libertad: "...no será obligado a hacer lo que la Constitución y las leyes no manden, ni a privarse de los que éstas no prohíban"7, para el servidor público o gobernante es exactamente lo contrario; es decir, lo que no le está permitido u autorizado por la norma se entiende que le está prohibido o vedado, por eso el art. 122 de la Constitución sostiene que: "son nulos los actos de las personas que usurpen funciones que no les competen, así como los actos de las que ejercen jurisdicción o potestad que no emane de la ley"; de esa manera, el texto constitucional concilia el poder con la libertad y la seguridad.

- División o separación de órganos de poder del Estado, que busca evitar la concentración del poder y permitir el control mutuo entre los diversos órganos de poder. En este contexto, es posible sostener que si básicamente un estado de derecho implica que un ciudadano cualquiera puede demandar al Estado o a una transnacional y tiene la posibilidad de ganar; se tiene que, en esencia, el elemento central y definitivo de un estado de derecho es la existencia de un juez imparcial e independiente que asegure la vigencia de la ley y la vigencia

\footnotetext{
${ }^{5}$ Confróntese Bolivia, Constitución Política del Estado, 2009, Artículo 410-II.

${ }^{6}$ Confróntese BolıviA, Constitución, cit. nota n. 5, Artículo 9-4.

${ }^{7}$ BoliviA, Constitución cit. nota n. 5, Artículo 14-IV.
} 
de los derechos y garantías, aclarándose además que dicha independencia e imparcialidad únicamente puede verificarse en la fundamentación de sus decisiones $^{8}$.

Por su parte, la acción de cumplimiento en este contexto busca reducir la brecha existente entre la realidad (el ser) y lo previsto en la norma (el deber ser $)^{9}$, por lo que su existencia sólo puede explicarse en el marco del estado de derecho. En este sentido, el cumplimiento de la normativa es de orden público constitucional al:

- Permitir el mantenimiento de las condiciones básicas para el ejercicio de los derechos.

- Efectivizar la garantía de separación de poderes, pues la administración pública estaría por encima del propio legislador si tuviese la libertad discrecional de decidir las leyes que cumplirá y las que no cumplirá, de esta forma, también se resguarda el principio democrático que impele a que las leyes deban emerger de un debate público y de un órgano representativo de mayorías y minorías.

- Hacer previsibles las conductas humanas, es decir, otorga certeza a las relaciones jurídicas y permite la realización de la seguridad jurídica entendida como la: "...condición esencial para la vida y el desenvolvimiento de las naciones y de los individuos que la integran. Representa la garantía de la aplicación objetiva de la ley, de tal modo que los individuos saben en cada momento cuáles son sus derechos y sus obligaciones, sin que el capricho, la torpeza o la mala voluntad de los gobernantes pueda causarles perjuicio" (AC 0287/1999-R).

- Resguardar en general el principio de igualdad, el principio de constitucionalidad y el principio de legalidad, así la SC 1294/2011-R sostuvo que "...el deber de cumplir lo dispuesto en las normas constitucionales y legales tiene su fundamento en el principio de legalidad y supremacía constitucional, en la seguridad jurídica, y en la necesidad de garantizar las condiciones necesarias para el pleno ejercicio de derechos y garantías; el incumplimiento de dicho deber indubitablemente genera una amenaza para el normal desarrollo de los mismos..."10.

- Constituirse en un mecanismo de democracia directa en la medida en la que permite la participación de los gobernados en asuntos de interés público como lo es el cumplimiento de la normativa vigente (art. 11.I.1 de la CPE).

\footnotetext{
${ }^{8}$ ArIAS LóPEZ, Boris Wilson, Teoría Constitucional y Nueva Constitución Política del Estado, Editorial El Original San José, El Alto-Bolivia, 2010, p. 34.

${ }^{9}$ Debe recordarse que desde tiempos de la colonia se maneja popularmente el aforismo de: "la ley se acata pero no se cumple".

${ }^{10}$ La SC 1765/2011-R estableció por su parte que el cumplimiento de la ley es una garantía de los ciudadanos y deber de las autoridades que asegura: "1) Derecho de igualdad... piedra angular del Estado Social y Democrático de Derecho... 2) La seguridad jurídica... garantiza en el colectivo una conciencia de respeto y previsibilidad del comportamiento de las autoridades en la aplicación de la ley... 3)... principio de supremacía constitucional...".
} 
- Efectivizar el deber fundamental de: "Conocer, cumplir y hacer cumplir la Constitución y las leyes" contenido en el art. 108.1 de la CPE.

Puede concluirse, entonces, que la misma justificación de la necesidad del cumplimiento de la normativa vigente, a la vez, legitima a la acción de cumplimiento.

\section{3. ¿LOS DERECHOS SUBJETIVOS SON}

TUTELADOS POR LA ACCIÓN DE CUMPLIMIENTO?

El presente título necesariamente trae a colación el interesante debate producido por el Tribunal Constitucional peruano, así y considerando que la acción de cumplimiento en el Perú procede para efectivizar mandatos emergentes de leyes o actos administrativos, el exp. 191-2003-AC/TC sostuvo que la: “...acción de cumplimiento es un 'proceso constitucionalizado' que, prima facie, no tiene por objeto la protección de un derecho o principio constitucional, sino la de derechos legales y de orden administrativo, mediante el control de la inacción administrativa", pero en el exp. 0168-2005-PC/TC se sostuvo su carácter constitucional al tutelar un derecho innominado, es decir que: "...el control de la regularidad del sistema jurídico en su integridad constituye un principio constitucional básico en nuestro ordenamiento jurídico nacional... no sólo basta que una norma de rango legal o un acto administrativo sea aprobado cumpliendo los requisitos de forma y fondo... y que tengan vigencia; es indispensable, también, que aquellas sean eficaces... Es sobre la base de esta última dimensión que... el Tribunal Constitucional reconoce la configuración del derecho constitucional a asegurar y exigir la eficacia de las normas legales y de los actos administrativos. Por tanto, cuando una autoridad o funcionario es renuente a acatar una norma legal o un acto administrativo... surge el derecho de defender la eficacia de las normas... a través del proceso constitucional de cumplimiento".

Dicho debate fue pasado por alto por el Tribunal Constitucional boliviano que en el primer fallo resuelto de acción de cumplimiento, es decir, que en la SC 0258/2011-R se sostuvo que: "En Bolivia... la acción de cumplimiento está configurada como un verdadero proceso constitucional, por las siguientes razones: i) Está configurada procesalmente por la Constitución Política del Estado; ii) Su conocimiento y resolución es de competencia de la justicia constitucional; iii) Tiene como objeto -conforme se verá-garantizar el cumplimiento de la Constitución y la ley y, en tal sentido, protege el principio de legalidad y supremacía constitucional y la seguridad jurídica; y, iv) Tutela de manera indirecta derechos fundamentales y garantías constitucionales-como se analizará posteriormente-" ${ }^{\prime 11}$.

\footnotetext{
${ }^{11}$ Este debate en Bolivia parece más propio del Ilamado Recurso Directo de Nulidad.
} 
La omisión reflexiva por parte del órgano de control de constitucionalidad sobre el objeto procesal de la acción de cumplimiento produjo la conclusión de que la acción de cumplimiento es de carácter tutelar, de forma que: “...puede estar directa o indirectamente vinculado a la lesión de derechos fundamentales o garantías constitucionales..." (SC 258/2011-R). En este contexto ¿qué tipo de derechos exactamente tutela la acción de cumplimiento?

La respuesta resulta fundamental para precisar los límites entre el ámbito de protección del amparo constitucional por omisión y el de la acción de cumplimiento.

Sostener que el objeto de la acción de cumplimiento es la tutela de derechos subjetivos resultaría irrazonable en la medida en la que se constituiría en un razonamiento que contrariaría a la ratio essendi que inspiró la creación de esta acción constitucional; así la Constitución en su artículo 134-I al instaurar la acción de cumplimiento es clara al establecer que: "La acción de cumplimiento procederá en caso de incumplimiento de disposiciones constitucionales o de la ley por parte de servidores públicos, con el objeto de garantizar la ejecución de norma omitida", sin hacer referencia alguna a la tutela de derechos.

En este mismo sentido, en el derecho comparado se tiene la sentencia SU476 de 1997 de la Corte Constitucional colombiana y el exp. NN 2763-2003-AC/ TC del Tribunal Constitucional peruano.

Si partimos de una interpretación sistemática de la Constitución, el propósito de la acción de cumplimiento no se reduce a la efectivización de un deber fundamental o legal, sino a la realización del orden constitucional y del orden legal, que a su vez se constituye en la condición necesaria para el ejercicio de los derechos, valores y principios constitucionales.

Por otra parte, no puede negarse que los derechos fundamentales se encuentran desarrollados por la ley, por lo que al cumplir la ley también se tutelan los derechos pero no en su dimensión subjetiva o colectiva sino en su dimensión objetiva, que incluso pueden develarse a través de un caso concreto, de donde se extrae que la protección de un derecho en su dimensión objetiva puede ser directa o indirecta y la protección excepcional de un derecho subjetivo mediante una acción de cumplimiento siempre es indirecta.

En la jurisprudencia, la SC 1765/2011-R diferenció entre la acción de cumplimiento y el amparo constitucional sosteniendo que la garantía del cumplimiento de la normativa: " ... responde precisamente a una visión de 'construcción colectiva del Estado'... De lo expresado precedentemente, puede establecerse una diferencia esencial entre la acción en análisis y las acciones de libertad, amparo y protección de privacidad, toda vez que estas últimas, son acciones tutelares cuyo objetivo es el resguardo a derechos fundamentales pero sin una 
afectación o incidencia directa en la colectividad...", aspecto que resulta sin duda plenamente lógico.

En este contexto, a efectos del análisis de la distinción entre acción de cumplimiento y la acción de amparo corresponde citar la siguiente jurisprudencia:

- En la SC 1294/2011-R la parte accionante sostuvo que una Sala Penal de la entonces Corte Suprema de Justicia -ahora Tribunal Supremo de Justicia- omitió cumplir el art. 420 del CPP al no utilizar la doctrina legal que en criterio del accionante era aplicable a su caso, denegándose la tutela por parte del Tribunal Constitucional porque: "...si el deber omitido... se trata de un deber genérico, pero vinculado a la lesión de derechos o garantías fundamentales -como por ejemplo el deber de motivación de las resoluciones cuyo incumplimiento general lesiona al debido proceso- corresponde la formulación de la acción de amparo constitucional por omisión...".

- En la SC 1765/2011-R la parte accionante solicitó que la Gobernación demandada cumpla el art. 31 de la LEPA que establece que si se gana un concurso arquitectónico debe darse la licitación y pagarse según el arancel del colegio de arquitectos, denegándose la tutela por el Tribunal Constitucional porque si bien el supuesto: "...constituye una situación evidentemente prevista en la ley, pero que en definitiva beneficia a un particular; aspecto que no se puede asumir como una situación de construcción colectiva del Estado... más al contrario, se puede verificar de manera absolutamente evidente que el reclamo planteado tiene como objeto el alcance de un beneficio aislado...".

- En la SC 1534/2011-R, en el caso concreto, la accionante opuso recurso de revocatoria contra un memorando por considerar aplicable la Ley de Procedimiento Administrativo, pero el Tribunal Constitucional entendió que la accionante como funcionaria de carrera del Consejo de la Judicatura debió adecuar su impugnación a los parámetros del Reglamento de Carrera Administrativa del Poder Judicial y a la vez se observó que pese a ello se omitió la remisión del recurso jerárquico al superior "... imperativo constitucional contenido en el art. 180.II de la Ley Fundamental, de cuyo tenor se extrae la garantía del principio de impugnación, que converge en el derecho de oponerse a las decisiones jurisdiccionales -tanto judiciales como administrativas-en una interpretación extensiva del texto constitucional, favorable a la protección de derechos, garantías y principios constitucionales...", aspecto que llevó a conceder la tutela solicitada.

- En la SC 1750/2011-R se concedió la tutela de la acción de cumplimiento respecto a un accionante que alegaba haber sido destituido de su fuente laboral sin que se haya considerado su condición de progenitor de un menor de cinco meses, por lo que se entendió el desconocimiento de las normas que garantizaban su inamovilidad laboral hasta que su hijo cumpla un año de edad.

- En la SC 1325/2011-R el accionante alegó la iniciación de procesos disciplinarios sin que previamente se haya conformado una comisión investi- 
gadora, pero se denegó la tutela porque: “... los accionantes no han acreditado que ese reclamo hubieran efectuado oportunamente dentro de los procesos disciplinarios de referencia, porque... el principio de subsidiaridad que caracteriza a la acción de cumplimiento obliga a que la parte afectada previamente acuda en este caso ante el Tribunal Sumariante solicitando el cumplimiento de los arts. 42.1 y $45 . I I$ de la LCJabrg, que hoy acusa de no observados por los demandados".

El entendimiento y resultado de la SSCC 1534/2011-R, 1750/2011-R, que hace referencia a la imposibilidad de tutelar derechos subjetivos mediante la acción de cumplimiento, es totalmente opuesto al contenido en las SSCC 1294/2011-R, 1765/2011-R, que tutelaron derechos subjetivos, lo que devela la falta de claridad de la jurisprudencia constitucional, que en general confunde la acción de cumplimiento con el amparo constitucional por omisión.

En la SC 1325/2011-R el entendimiento es incluso más ambiguo porque se rechaza la acción de cumplimiento por subsidiariedad pero no se precisa si agotadas las instancias procedía el amparo constitucional por omisión o la acción de cumplimiento.

Sin duda alguna el falso debate de la protección de derechos por la acción de cumplimiento en Bolivia se originó de la deficiente redacción del art. 87 de la Ley del Tribunal Constitucional Plurinacional -norma ahora abrogada por el Código Procesal Constitucional- que disponía que: “...tiene por objeto la defensa de los derechos constitucionales de las personas naturales o jurídicas, garantizando el cumplimiento del deber omitido por parte de los funcionarios o autoridades públicas, a lo ordenado por la Constitución Política del Estado o la ley", aspecto corregido por el art. 64 del Código Procesal Constitucional que siguiendo al art. 134-I de la CPE establece que: "La Acción de Cumplimiento tiene por objeto garantizar la ejecución de la norma constitucional o legal, cuando es omitida por parte de Servidoras o Servidores Públicos u Órganos del Estado", sin hacer referencia a la tutela de derechos.

Entonces, habiéndose llevado a confusión al ciudadano sobre la vía procesal adecuada para la protección del ciudadano en sus derechos e intereses por el legislador ordinario e incluso por el órgano de control de constitucionalidad durante el denominado estado de transición constitucional ${ }^{12}$, es razonable la reconducción de oficio por parte del Tribunal Constitucional Plurinacional de las demandas de acción de cumplimiento hacia una demanda de amparo

\footnotetext{
${ }^{12}$ La SC 0158/2010-R sostuvo que: "... 'estado de transición constitucional' en el marco del cual se liquidarán las causas pendientes de resolución... los Tratados Internacionales referentes a Derechos Humanos, estuvieron en plena vigencia en el momento de iniciarse las causas pendientes de resolución y permanecen actuales en la etapa de transición constitucional... En consecuencia, en la especie, corresponde aplicar el bloque de constitucionalidad conformado por la Constitución vigente, los Tratados Internacionales referentes a Derechos Humanos y principios y valores de rango constitucional...".
} 
constitucional y viceversa, todo ello en atención a los principios de economía procesal, eficacia de los derechos fundamentales, verdad material -prevalencia del derecho sustantivo sobre el derecho adjetivo-, pro actione siempre y cuando:

- No se modifiquen los hechos que sustentan la demanda.

- Se cumplan los requisitos inexcusables de la otra demanda (de amparo constitucional y viceversa).

- Se evidencie error en la vía procesal elegida.

- No exista necesidad de producir prueba adicional o extraordinaria.

- No se provoque indefensión a la parte demandada, es decir, que la misma haya tenido la oportunidad de contraponerse a la pretensión de la parte demandante.

Ello no es extraño en el derecho comparado, así en la jurisprudencia del Tribunal Constitucional peruano es admisible la mutación de una acción de cumplimiento a una de amparo constitucional, por ejemplo:

- En el exp. № 2763-2003-AC/TC se sostuvo que en el caso concreto: “...el objeto de la demanda no es tanto demandar el cumplimiento de la Ley $N^{\circ} 27.550$, sino más bien cuestionar un comportamiento lesivo de derechos constitucionales, y que por ello la vía idónea para resolver la controversia no es la acción de cumplimiento, sino el amparo. Aunque en aplicación del principio de suplencia de la queja deficiente, previsto en el artículo $7^{\circ}$ de la Ley $N^{\circ} 23.506$, se podría declarar la nulidad del procedimiento seguido y devolver los actuados al juez competente a efectos de que la pretensión sea tramitada como amparo, este Tribunal considera innecesaria la aplicación de tal principio, habida cuenta de la urgencia de restituir los derechos reclamados y de la correlativa necesidad de que el presente proceso se resuelva de forma oportuna y efectiva, de modo que se pronunciará de inmediato sobre el fondo de la controversia..." procediéndose en su parte resolutiva a "Declarar FUNDADA la demanda interpuesta, la que debe entenderse como acción de amparo".

- En el exp. № 4080-2004-AC/TC se hizo referencia a que: "...El recurrente manifiesta que su pretensión consiste en que se cumpla con lo establecido en la Ley $N^{\circ} 27684$, es decir, que se destine el 3\% del presupuesto de los recursos ordinarios de la Unidad de Gestión Educativa de Chincha para el pago de las sentencias en calidad de cosa juzgada. Es decir, lo que el demandante realmente pretende es lograr la eficacia de una sentencia emitida en un proceso anterior... Ello no obstante, no puede ventilarse en un proceso de cumplimiento, puesto que las decisiones judiciales para su ejecución no requieren de ninguna actuación adicional de la jurisdicción y deben cumplirse por su sólo mérito... (pero)... en aplicación del principio iura novit curia... este Colegiado entiende que en el presente caso, en correspondencia con los principios del proceso constitucional recogidos en el artículo III del Título Preliminar del Código Procesal Constitucional 
(principios de dirección judicial del proceso y economía procesal), así como de suplencia de la queja deficiente... resulta necesario adecuar el presente proceso a las reglas del proceso de amparo y resolver con arreglo a ellas" para finalmente: "Declarar FUNDADA la demanda, adecuada por este Tribunal...".

- En el exp. № 0569-2003-AC/TC se dispuso que al recurrente se le otorgue pensión de renta vitalicia por enfermedad profesional y el pago de devengados, aspecto que corresponde sin duda al amparo constitucional, sosteniéndose entre otros que: "... a diferencia de las situaciones resueltas sobre la base de la aplicación del principio de suplencia de queja deficiente, por aplicación del aforismo iura novit curia, el juez tiene el poder-deber de identificar el derecho comprometido en la causa, aun cuando no se encuentre expresamente invocado en la demanda... lo que no implica, en ningún caso, la modificación del objeto de la pretensión o de los términos de la demanda; es decir, que ello no puede suponer fundar su decisión en hechos diversos de los que han sido alegados por las partes...".

Similar razonamiento debe aplicarse respecto a los derechos colectivos tutelados en Bolivia por la acción popular, es decir, puede tutelarse un derecho colectivo en su dimensión objetiva cuando esté relacionado al cumplimiento de una norma constitucional o legal en su sentido material.

En el derecho comparado, respecto a la tutela de los derechos colectivos, en el exp. N No 2002-2006-PC/TC el Tribunal Constitucional peruano ordenó el cumplimiento de la Ley № 26.842 que disponía se efectúe un "Plan Integral para Disminuir la Contaminación Ambiental en La Oroya" una de las ciudades más contaminadas en América. Entonces se sostuvo que: “...si bien los derechos a la salud y a un medio ambiente equilibrado y adecuado no podrían ser protegidos 'directamente' mediante el proceso de cumplimiento, sí pueden ser tutelados de modo 'indirecto', siempre y cuando exista un mandato claro, concreto y vigente, dispuesto en una ley o un acto administrativo, que se encuentre indisolublemente ligado a la protección de tales derechos fundamentales".

En este contexto, puede concluirse parcialmente respecto a la acción de cumplimiento que:

- El único derecho subjetivo que puede tutelarse por la acción de cumplimiento es el de defender la eficacia de las normas constitucionales y legales en su sentido material.

- En el objetivo de efectivizar la normativa y los deberes de orden constitucional y legal es posible otorgarse tutela directa a los derechos individuales o colectivos en general, pero en su dimensión objetiva, sin perjuicio de que eventualmente pueda tutelarse de forma indirecta derechos subjetivos.

- Cuando se evidencia que la parte accionante confundió la vía legal, es posible que la acción de cumplimiento pueda reconducirse o mutarse en una acción de amparo constitucional o a la acción popular dependiendo el caso y viceversa. 


\section{Características de la acción De CUMPLIMIENTO}

La acción de cumplimiento se caracteriza por lo siguiente:

Es una acción constitucional que conforme el art. 134-I de la Constitución Política del Estado: “...procederá en caso de incumplimiento de disposiciones constitucionales o de la ley por parte de servidores públicos, con el objeto de garantizar la ejecución de la norma omitida".

Tiene por objeto la efectivización de normas constitucionales y de orden legal (art. 134-I de la CPE), constituirse en medida efectiva para obligar al cumplimiento de un deber omitido claramente identificado (art. 10-1 de la CPE), además de efectivizar el derecho subjetivo constitucional a asegurar y exigir la eficacia de normas de carácter constitucional y normas legales en su sentido material.

Es posible su interposición mientras subsista la omisión, aspecto que trae aparejada la sustracción de la materia o pérdida del objeto procesal en aquellos casos en los que la norma que imponía el deber haya sido derogada, pues en principio en el marco del punto anterior mediante la acción de cumplimiento no es posible tutelar derechos subjetivos y sus respectivas garantías, lo que incluye por supuesto a la garantía de la irretroactividad de la ley (art. 123 de la CPE).

En coherencia con los dos puntos anteriores, la acción de cumplimiento tampoco tiene por objeto principal la indemnización por perjuicios causados por el incumplimiento a normas de orden constitucional o de orden legal en sentido material, aunque la misma pueda disponerse de manera colateral o pueda acudirse a órganos jurisdiccionales ordinarios para su determinación e imposición (Sentencia C-638/00 de la Corte Constitucional de Colombia).

Los jueces y tribunales de garantías así como el Tribunal Constitucional Plurinacional pueden controlar de oficio la constitucionalidad de una ley -control de constitucionalidad difuso- lo que es lógico si se considera que conforme el AC 0263/2010-CA “...dada la naturaleza jurídica y los derechos tutelados por la acción de amparo constitucional, no es posible la interposición del recurso o acción indirecta o incidental de inconstitucionalidad; el cual, en caso de ser presentado, ante los jueces y tribunales de garantías, sea antes o en audiencia, corresponderá ser rechazado 'ad portas'...", aspecto que concuerda con el art. 81 del Código Procesal Constitucional.

La acción de cumplimiento puede plantearse de forma preventiva, así en el derecho comparado la sentencia C-010/01 de la Corte Constitucional de Colombia sostuvo: "... si bien materialmente aún no se ha producido la omisión del deber concreto, de las acciones u omisiones de la autoridad responsable es posible deducir que existe una real expectativa de que éste se produzca de manera 'inminente', esto es que exista el riesgo de que suceda prontamente'. 
Al igual que sucede con el resto de acciones constitucionales, es posible que se declare el estado de cosas institucional, así en el exp. № 3149-2004-AC/ TC del Tribunal Constitucional peruano se hizo referencia a diferentes casos en los cuales la parte demandada había mostrado su renuencia a pagar el derecho por concepto de luto y sepelio declarándose el estado de cosas inconstitucional, donde se aclaró que: "...la técnica de la declaración del Estado de Cosas Inconstitucional, desarrollado de manera creativa por la Corte Constitucional colombiana, con el objeto de expandir los alcances de la sentencia en un proceso de tutela de derechos fundamentales con efectos, prima facie, inter partes, evitando que otros ciudadanos afectados por los mismos comportamientos violatorios tengan que interponer sucesivas demandas con el fin de lograr lo mismo".

\section{TIPOLOGÍA DE NORMAS Y CLASES DE INCUMPLIMIENTO}

A diferencia de lo que sucede en la legislación peruana y colombiana, en la que la acción de cumplimiento procede para efectivizar el cumplimiento de normas de orden legal y de los actos administrativos, en Bolivia la acción de cumplimiento se activa para efectivizar mandatos de:

5.1. El bloque de constitucionalidad que integra a la Constitución Política del Estado a los tratados en derechos humanos y de derecho comunitario. En este caso se resguarda además el principio de supremacía constitucional (art. 410-II de la Constitución Política del Estado).

En el derecho comparado, por una parte, la Corte Constitucional colombiana en la sentencia C-651/03 negó la posibilidad de solicitar el cumplimiento de normas constitucionales mediante la acción de cumplimiento, entendiendo que las mismas, a diferencia de la normas legales por su lenguaje indeterminado y abierto -derivado del consenso político y la función social de la Constituciónrequieren de interpretación previa permitiendo un alto grado de discrecionalidad, lo que a criterio de la referida Corte no condice con la naturaleza de la acción de cumplimiento. Esa posición es contradictoria si se considera que dicha Corte reconoce que la Constitución ya no sólo es un documento político -al establecer valores y principios- sino normativo, por lo que en su caso y, bajo esa lógica, debió al menos diferenciarse entre los principios y las reglas que contiene la Constitución, pudiendo las reglas cumplirse mediante la acción de cumplimiento.

El Tribunal Constitucional peruano fue más amplio en este aspecto, así en el exp. 5427-2009-PC/TC ante la solicitud de que el Ministerio de Energía y Minas adecue sus "normas", "reglamentos" y "directivas" al Convenio 169 de la OIT en lo referido a la consulta previa, se entendió que si bien dicha norma formaba parte del bloque de constitucionalidad "...el presente proceso de 
cumplimiento debe ser adecuado o redimensionado para dar respuesta a la pretensión planteada por la parte demandante..." y tras concluir que tras 15 años desde la ratificación del Convenio 169 de la OIT, plazo más que razonable para desarrollar la consulta previa en materia minera, existía un incumplimiento parcial a dicho deber, pues el reglamento mismo existente no se encontraba adecuado a los parámetros del bloque de constitucionalidad.

En otro caso, la Ley № 26.655 había creado una Comisión especial o ad hoc para identificar a personas condenadas en el Perú con error judicial y las mismas una vez identificadas solicitaron el cumplimiento del art. 14.6 del Pacto Internacional de Derechos Civiles y Políticos, que reconoce indemnización a las personas beneficiadas con un indulto como consecuencia de la comisión de error judicial, y mediante sentencia 1277-99-AC/TC el Tribunal Constitucional peruano declaró fundada la demanda. Ello es lógico porque los tratados de derechos humanos no sólo forman parte del bloque de constitucionalidad, tienen carácter normativo y no meramente declarativo, se presumen y en general son operativos y comprometen la responsabilidad internacional de los Estados, en nuestro caso del Estado boliviano.

5.2. La ley entendida en su sentido material en razón a que:

- Debe realizarse una interpretación con efecto útil en la medida en la que entre una interpretación que no produzca efecto jurídico y la que sí la produzca, debe remitirse a la interpretación que sí produce el efecto, máxime cuando la misma, como en el caso concreto, está vinculada a la noción de estado de derecho.

- La configuración del Estado boliviano incluye "...autonomías..." (art. $1^{\circ}$ de la CPE) que conforme el art. 272 de la propia Constitución Política del Estado implica la posibilidad del: "...ejercicio de las facultades legislativas..." que en este contexto involucra que la legislación autonómica departamental, municipal e indígena originaria campesina tengan rango normativo equivalente al de la ley nacional, conforme puede desprenderse del art. 410-II-3 de la CPE ${ }^{13}$.

La SC 0258/2011-R entendió que la acción de cumplimiento: “...está vinculado a garantizar el cumplimiento de un deber contenido en: a) Normas constitucionales, las cuales, como se ha visto, tienen un valor normativo inmediato y directo y a cuya observancia están obligados los servidores públicos y los particulares (arts. 9.4, 108 numerales 1, 2 y 3 y 410 de la CPE); b) La Ley, entendida no en el sentido formal -como originada en el órgano legislativo-sino

\footnotetext{
${ }^{13}$ Entendimiento similar se siguió en la sentencia C-893/99 respecto expresiones "con fuerza material de ley" o "con fuerza de ley". La doctrina distingue ley en sentido formal donde prima el criterio orgánico y la ley en sentido material que regula una materia sin provenir del legislativo (formalmente no es una ley tiene sin embargo debido al sistema de fuentes desarrollado en la Constitución el mismo rango jerárquico que las leyes y, por ende, puede derogar y modificar otras leyes y no puede alterarse sino por normas de igual o superior jerarquía).
} 
material, sin importar la fuente de producción, abarcando, por tanto, a decretos supremos, resoluciones supremas, la legislación departamental y municipal, a cuyo cumplimiento también se obligan los particulares y los servidores públicos (arts. 14.V y 108.1 de la CPE)"; dicha aseveración incluye a decretos supremos y resoluciones supremas emergentes del Poder Ejecutivo sin realizar razonamiento alguno, por lo que per se desconoce no sólo el sistema de fuentes sino el principio de jerarquía normativa reconocida por la Constitución (art. 410.II de la CPE).

Por ello, si bien es evidente que para efectivizar un mandato constitucional o de orden legal puede además requerirse el cumplimiento de una norma reglamentaria e incluso de un acto administrativo, ello se lo hace de manera accesoria y subordinada al mandato constitucional o legal, pero no de forma independiente y principal, es decir, por ejemplo, no resulta posible solicitar únicamente el cumplimiento de un decreto supremo sino de la ley desarrollada por un decreto supremo.

En todo caso, cuando mediante la acción de cumplimiento se efectiviza el mandato contenido en un Decreto Supremo respecto a una autoridad del propio Órgano Ejecutivo, se cumple con el principio de auto-vinculación administrativa, ello en razón a que en esos casos justamente es la propia administración pública la que debe cumplir la normativa que elaboró en desarrollo y precisión de la legislación vigente.

\section{Del concepto de estado de RENUenCia}

A pesar de que el texto constitucional expresamente no refiere en su art. 134-II al concepto de estado de renuencia, se entendió como un requisito implícito a la acción de cumplimiento que posteriormente se hizo explícito en el Código Procesal Constitucional, cuyo art. 66.2 establece como causal de improcedencia "Cuando el accionante no haya reclamado previamente y de manera documentada a la autoridad accionada, el cumplimiento legal del deber omitido"14.

El estado de renuncia de una autoridad pública refiere a la necesidad de la parte accionante de que previamente al planteamiento de la acción de cumplimiento requiera, mediante documento de fecha cierta, a la autoridad competente el cumplimiento de la norma constitucional o de orden legal, ratificándose dicha autoridad en su renuencia de forma expresa o al no contestar a la solicitud de cumplimiento formulada en el plazo que la norma administrativa le obligue a responder.

\footnotetext{
${ }^{14}$ Dicho requisito también podía extraerse de alguna manera del art. 89-5 de la Ley del Tribunal Constitucional Plurinacional que establecía que se constituía en causal de improcedencia de la acción de cumplimiento el que: "... el accionante no haya reclamado con anterioridad y de manera documentada a la autoridad accionada, el cumplimiento legal o administrativo del deber omitido".
} 
La importancia de constituir a una autoridad en estado de renuncia previamente al planeamiento de la acción de cumplimiento fue ampliamente desarrollada por la Corte Constitucional de Colombia en la sentencia C-1194-01, donde se sostuvo que la constitución en renuencia permitía:

- Constatar el incumplimiento y delimitar el ámbito del deber omitido, es decir: "...identificar los elementos específicos y determinados, así como sus modalidades respecto de las circunstancias de tiempo, modo y lugar, que pudo haber empleado la norma incumplida, para precisar sus alcances...".

- Identificar a la autoridad renuente titular del deber jurídico omitido, y en el caso de no constituirse en la autoridad competente en base al principio de informalismo que rige la actuación de la administración pública, remitir la solicitud a la autoridad competente o al menos señalar al solicitante la misma.

- Se da la oportunidad a la administración pública para cumplir el deber omitido, o para que se exponga al solicitante las razones que justifican su inactividad.

El Tribunal Constitucional peruano en el exp. 191-2003-AC/TC sostuvo que: "...mediante la acción de cumplimiento no se controla la mera o simple inactividad administrativa, sino aquella que asume la condición de 'renuente'..." requerimiento notarial que se constituye en presupuesto procesal subjetivo que: "...persigue que se demuestre que no se trata de un simple letargo administrativo, sino que la autoridad responsable persiste en la inacción, pese a que el afectado en sus intereses legítimos le ha recordado que existe un mandato contenido en la ley o en un acto administrativo que aún no se ha cumplido...".

En Bolivia el Tribunal Constitucional también entendió dicho requisito implícito, por ejemplo, en la SC 1386/2011-R sostuvo que: “...debe demostrarse la actitud renuente -manifiesta y fehaciente- de la autoridad demandada, que puede deducirse de su silencio prolongado; al efecto y con relación al plazo de caducidad, ante la ausencia normativa sobre el pronunciamiento oportuno del funcionario o la autoridad pública, es menester remitirse supletoriamente el art. 71.I inc. g) del D.S. 27.113 de 23 de julio de 2003, referente al Reglamento a la Ley de Procedimiento Administrativo, disposición que taxativamente señala que las decisiones sobre cuestiones de fondo, deben ser resueltas en veinte días cuando no exista un plazo expresamente señalado".

Pese a ello, en la jurisprudencia boliviana existe tendencia a confundir el estado de renuencia con la subsidiariedad, así la SCP 0036/2012 sostuvo: “...con relación al principio de subsidiariedad, la naturaleza de la acción de cumplimiento, determina que previamente a su presentación, es necesario que el actor haya solicitado el cumplimiento de la ley o leyes expresamente determinadas a la autoridad demandada, caso contrario no se activa la jurisdicción constitucional para la tutela demandada..." cuando la acción de cumplimiento no se rige por el principio de subsidiariedad que caracteriza en 
realidad al amparo constitucional, es decir, no puede exigirse el agotamiento de instancias previas porque no se está solicitando el reconocimiento de un derecho subjetivo sino el cumplimiento de una norma cuya validez y vigencia no es objeto de debate, así la SC 1765/2011-R de forma parcialmente correcta sostuvo que: "...es absolutamente pertinente resaltar que en caso de existir una instancia superior a aquella autoridad renuente en el cumplimiento de un mandato inserto en la Constitución Política del Estado o la ley, no será necesario impugnarla, puesto que -como ya se dijo-, el principio de no supletoriedad de la acción de cumplimiento no puede equiparse al principio de subsidiaridad aplicable a la acción de amparo constitucional, en ese contexto, con la resolución que resuelva la petición de cumplimiento, queda expedita la vía tutelar a través de la acción de cumplimiento", en este caso, también la aseveración debe precisarse pues si la negativa al cumplimiento de la norma pudiese impugnarse no procedería la acción de cumplimiento porque la ley no se debate sino se cumple.

Este aspecto resulta evidente si se diferencia con claridad entre inactividad formal e inactividad material, como lo hizo el Tribunal Constitucional peruano en el exp. 191-2003-AC/TC al sostener que: "...la acción de cumplimiento protege derechos e intereses legítimos de los administrados que se deriven de la inacción de los órganos de la Administración pública... (que)... ha venido siendo considerada por este Tribunal bajo el título genérico de 'inactividad material de la administración'... En efecto, mediante la acción de cumplimiento no se controla cualquier clase de inactividad, sino exclusivamente la que se ha denominado 'material', es decir, la que deriva del incumplimiento de mandatos nacidos de la ley o de actos administrativos, donde no media la petición de un particular, sino donde se encuentra vinculado, prima facie, un deber o el ejercicio de una atribución relacionada con sus competencias naturales... Mediante la acción de cumplimiento no se controla la denominada 'inactividad formal de la administración', es decir, la que se origina tras el ejercicio del derecho de petición por un particular, pues ésta tiene su instrumento natural de control en la técnica del silencio administrativo negativo, cuyos efectos procesales -derivados de su acogimiento- tienen el propósito de no dejar en estado de indefensión al administrado que hubiese peticionado algo o hubiese interpuesto un medio impugnatorio en el seno de un procedimiento administrativo y que, pese a ello, no hubiese recibido algún pronunciamiento expreso..." ${ }^{\prime 15}$.

Por su parte, la SC 1765/2011-R estableció: “...la apertura de un procedimiento administrativo o uno judicial, dentro de los cuales debería agotarse las instancias existentes, constituye una causal de exclusión de tutela a través de

${ }^{15}$ Aunque debe hacerse referencia a la ambigüedad de dicho concepto en el Perú, así el Exp. № 74352006-PC/TC del Tribunal Constitucional peruano. 
la acción de cumplimiento... En efecto, contra esta petición previa -que no implique apertura de procedimiento administrativo o proceso jurisdiccional-, la autoridad que omitió el incumplimiento de un mandato inserto en una norma constitucional o la ley, tendrá el deber de resolverla, allanándose o no a dicha solicitud; en el primer caso, efectivamente el cumplimiento del deber omitido estará garantizado; empero, en el segundo supuesto, es decir, en caso de no allanarse la autoridad obligada a esta petición de cumplimiento, será precisamente esta decisión la que acredite el incumplimiento, momento a partir del cual, quedará expedita la tutela constitucional a través de la acción de cumplimiento".

Entre algunas de las particularidades del estado de renuencia podemos indicar que:

- El estado de renuencia puede entenderse como la resistencia dolosa o negligente de una o un servidor público titular de un deber jurídico a efectivizar la normativa constitucional y/o legal.

- Previamente al planteamiento de la acción de cumplimiento debe constituirse en renuencia a la parte demandada, salvo exista peligro inminente, en cuyo caso puede suprimirse ese requisito previo.

- La renuencia puede ser: expresa, es decir, cuando el servidor público expresamente se ratifica en su incumplimiento, o tácita, situación que se presenta cuando en el término previsto en la ley el servidor público no otorga justificación o explicación alguna que justifique su omisión.

- En la jurisprudencia boliviana la SC 1386/2011-R, respecto a la innecesaria solicitud de un informe legal para dar cumplimiento a una ley por parte de los demandados, provocó que se sostuviera que: “...renuencia por cumplir un deber constitucional o legal, no únicamente es demostrable a través de la negativa expresa de la autoridad o funcionario público demandados; caso contrario, se admitiría que una actitud evasiva y en apariencia diligente, pueda salvar la resistencia de cumplir lo ordenado por una norma constitucional o legal...".

- Por otra parte, a efectos de la renuencia tácita, resulta tener las mismas consecuencias no pronunciarse o haberse pronunciado pero no haber notificado dicho pronunciamiento.

- En este sentido, el Consejo de Estado colombiano en su Sala de lo Contencioso Administrativo -Sección Quinta, en el expediente 25000-23-27-0002003-1877-01(ACU) sostuvo: “...para probar la constitución de la renuencia expresa es necesario analizar tanto la reclamación del cumplimiento como la respuesta del destinatario del deber omitido, puesto que la primera delimita el marco del incumplimiento reclamado y la segunda circunscribe la competencia del juez constitucional en la acción de cumplimiento para analizar única y exclusivamente las normas que el demandado es renuente a cumplir. $Y$, para 
demostrar la renuencia tácita es necesario estudiar el contenido de la petición de cumplimiento que previamente debió formular el demandante, pues, como se dijo, aquella define el objeto jurídico sobre el cual versará el procedimiento judicial para exigir el cumplimiento de normas con fuerza material de ley o actos administrativos. No obstante... puede prescindirse del requisito de constitución de renuencia en aquellos casos en que el incumplimiento de la norma o acto administrativo cuya observancia se reclama genera el inminente peligro de sufrir un perjuicio irremediable apara el accionante, situaciones en las cuales debe, de un lado, sustentarse en la demanda $y$, de otro, demostrarse la inminencia del perjuicio irremediable".

\section{RESPECTO A LA PRECISIÓN DEL ESTADO DE RENUENCIA Y LA POSIBILIDAD DE PLANTEAR LA ACCIÓN DE CUMPLIMIENTO}

El tipo de estado de renuencia y su determinación a efectos del planteamiento de la acción de cumplimiento lógicamente deviene de la naturaleza y contenido de las normas jurídicas respecto de las cuales se pide el cumplimiento, así tenemos: ${ }^{16}$

Por el origen del mandato la renuencia puede derivar de la:

- Inactividad derivada de un mandato previsto en una norma con rango constitucional (bloque de constitucionalidad).

- Inactividad derivada de un mandato previsto en una norma de rango legal en sentido material.

En ambos casos procede la acción de cumplimiento pero no procede para pedir el cumplimiento de norma de carácter reglamentario o actos administrativos (no emanado de un órgano deliberativo plural cuya decisión resulte de un proceso de debate público), en cuyo caso únicamente puede ordenarse su cumplimiento de forma indirecta si precisara el ejercicio de un deber de rango constitucional o legal.

Por el alcance del incumplimiento podemos estar frente a:

- Inactividad total referida a situaciones en las que la autoridad no efectuó ninguna actividad dirigida al cumplimiento de la norma con rango constitucional o de orden legal. En este caso es fácilmente comprobable la renuencia, procediendo sin mayor debate la acción de cumplimiento.

- Inactividad parcial referida a situaciones en las que se efectuaron actividades insuficientes para el cumplimiento de una norma, de forma que la misma no llegó a efectivizarse. En este caso para la procedencia de la acción de cum-

\footnotetext{
${ }^{16}$ Para la presente clasificación se consideró la realizada por Edgar Carpio Marcos en "La acción de cumplimiento (con especial referencia al caso peruano)", en Derecho Procesal Constitucional del Colegio de Secretarios de la Suprema Corte de Justicia de la Nación A.C., coordinado por Eduardo Ferrer Mac-Gregor, Editorial Porrúa, México, 2003.
} 
plimiento debe efectuarse por parte del órgano jurisdiccional una valoración de la conducta desplegada por el servidor público.

Por la naturaleza del mandato impuesto:

- Inactividad respecto a actos referidos al ejercicio de potestades discrecionales, es decir, en los cuales existe un cierto margen de libertad en la apreciación de los servidores públicos, lo que, sin embargo, no implica arbitrariedad pues de todas formas la decisión debe estar debidamente fundamentada. En este caso, el juez constitucional en la acción de cumplimiento puede controlar el incumplimiento previo control de la razonabilidad de la decisión del servidor público para no cumplir el mandato constitucional o legal ${ }^{17}$.

- Inactividad respecto a actos de obligatorio cumplimiento. La norma en estos casos impone un deber de actuar cierto y concreto, por lo que el servidor público únicamente puede cumplir el mandato constitucional o de orden legal. En este caso no puede existir duda alguna sobre la procedencia de la acción de cumplimiento.

Por la condicionalidad o no del mandato:

- Inactividad derivada de un mandato condicional donde las obligaciones del servidor público recién se concretan cuando se producen los supuestos de hecho o de derecho previstos por la norma. Entonces únicamente cuando se cumplen esos supuestos se puede activar la acción de cumplimiento.

- Inactividad derivada de un mandato formulado incondicionalmente, es decir, no vinculado a elementos externos de la norma, en cuyo caso la procedencia de la acción de cumplimiento es indiscutible.

En función de la complejidad del mandato constitucional o legal, tenemos:

- Inactividad derivada de mandatos de instrumentalización compleja, en los cuales el incumplimiento no se origina en la negligencia o voluntad de la autoridad pública sino a obstáculos materiales como infraestructura insuficiente, falta de recursos humanos o económicos, etc., en cuyo caso el juez debe evaluar la complejidad y determinar un plazo razonable para dar efectividad al mandato normativo.

- Omisiones derivadas de mandatos de instrumentalización simple que deben cumplirse inmediatamente, en cuyo caso la procedencia de la acción de cumplimiento es claro.

Por la conservación o no de la inactividad:

- Inactividad subsistente referida a situaciones en las cuales la omisión está vigente, encontrándose, por lo tanto, la autoridad pública en renuencia permanente, en estos casos no debe existir un plazo para plantear la acción

${ }^{17}$ Confróntese Exp. № 2002-2006-PC/TC del Tribunal Constitucional peruano. 
de cumplimiento, sino que su planteamiento depende de la vigencia del deber fundamental o legal omitido.

- Inactividad administrativa insubsistente referida a situaciones en las que la obligación desapareció por cumplirse lo obligado en su totalidad o porque el mandato normativo desapareció, lo que sucede, por ejemplo, cuando la ley fue derogada o abrogada. Si durante la tramitación de la acción de cumplimiento llegará a producirse alguno de estos supuestos existe sustracción del objeto procesal que deba dar lugar a un fallo inhibitorio de la justicia constitucional.

Según se evidencie o no la omisión:

- Inactividad que deriva en arbitrariedad manifiesta, situación que se presenta cuando el mandato es claro, evidente y concreto, resultando el incumplimiento inequívoco y perceptible sin que se requiera de mayor probanza.

- Inactividad no manifiesta, que se presenta generalmente frente a mandatos de condiciones complejas respecto a las cuales se requiere reglamentación en cuyo caso procede la inconstitucionalidad por omisión o intensa actividad probatoria en cuyo caso tampoco puede activarse la acción de cumplimiento al no contar con etapa probatoria amplia.

Los anteriores supuestos deben combinarse en cada caso concreto para identificar el tipo y estado de renuencia.

Congruente con lo anterior, la Corte Constitucional de Colombia sostuvo respecto al deber omitido en una acción de cumplimiento que: "Dicho deber no es... el deber general de cumplir la ley, sino un deber derivado de un mandato específico y determinado. Este puede tener múltiples manifestaciones o modalidades, pero no tiene que consistir en una obligación clara, expresa y exigible porque el artículo 87 no consagró una acción de simple ejecución, sino una acción de mayor alcance. Para que pueda exigirse su cumplimiento el deber ha de predicarse de una entidad concreta competente, es decir, que existe jurídica y realmente y es destinataria del mandato contenido en la norma legal o administrativa..." (Sentencia C-1194-01); mientras que el Tribunal Constitucional peruano en el exp. 191-2003-AC/TC, respecto a las características del mandato contenido en la ley, sostuvo que: "...para que mediante un proceso de la naturaleza que ahora toca resolver -que, como se sabe, carece de estación probatoria-, se pueda expedir una sentencia estimatoria, es preciso que el mandato previsto en la ley o en un acto administrativo tenga determinadas características. Entre otras, debe tratarse de un mandato que sea de obligatorio cumplimiento, que sea incondicional y, tratándose de los condicionales, que se haya acreditado haber satisfecho las condiciones; asimismo, que se trate de un mandato cierto o líquido, es decir, susceptible de inferirse indubitablemente de la ley o del acto administrativo que lo contiene y, en lo que al caso se refiere, que se encuentre vigente". 
Posteriormente, en el exp. № 0168-2005-PC/TC se sostuvo que: “...para que el cumplimiento de la norma legal... además de la renuencia del funcionario o autoridad pública, el mandato contenido en aquellos deberá contar con los siguientes requisitos mínimos comunes:

a) Ser un mandato vigente.

b) Ser un mandato cierto y claro, es decir, debe inferirse indubitablemente de la norma legal o del acto administrativo.

c) No estar sujeto a controversia compleja ni a interpretaciones dispares.

d) Ser de ineludible y obligatorio cumplimiento.

e) Ser incondicional".

Dicho entendimiento se recogió por el Tribunal Constitucional de Bolivia en la SC 1294/2011-R, que además entendió que: “...sobre los derechos comprometidos que pueden ser invocados por los accionantes y la necesidad de que estos sean de posible cumplimiento y su naturaleza no sea compleja, es que, se debe comprender que, aunque éstos podrían encontrarse preceptuados en la Constitución Política del Estado y las leyes, existen algunos derechos los cuales necesitan de una realización programática y progresiva... Así pues, la acción de cumplimiento, debe basarse sobre aspectos reales, prácticos y posibles de ser cumplidos de manera inmediata...", aspecto último cuestionable si se considera que la tendencia del constitucionalismo es dar fuerza normativa a los principios y valores constitucionales.

\section{Legitimación ACtiva y PASIVA}

Respecto a la legitimación activa en la acción de cumplimiento tenemos a:

- Toda persona por sí "...o por otra a su nombre con poder suficiente" (art. 134-II de la CPE) en este sentido: "...cuando la Constitución hace referencia a que la acción debe presentarse por la persona individual o colectiva afectada, no exige una afectación directa de intereses, derechos o garantías, que implique la demostración de la amenaza o lesión de los mismos, sino una afectación indirecta, que se traduce en la incertidumbre sobre el pleno goce y ejercicio de los mismos. Así, por ejemplo, del incumplimiento de reglamentar una ley que reconozca determinados derechos, se deriva la inseguridad en el pleno ejercicio de los mismos y, por tanto, la afectación indirecta de los titulares de esos derechos" (SC 1325/2011-R).

- Personas colectivas de naturaleza privada o de naturaleza pública, es decir, incluso servidores públicos pueden acudir a la vía constitucional para solicitar el cumplimiento de normas constitucionales o legales ${ }^{18}$, lo que tiene mucho sentido si se considera la distribución de competencias que efectúa la Constitución entre el nivel central y los gobiernos autónomos.

${ }^{18}$ Confróntese Corte Constitucional de Colombia, Sentencia C-1194-01. 
- La Defensoría del Pueblo (art. 222-1 de la CPE y art 65.3 del Código Procesal Constitucional).

- El Ministerio Público (art. 652 del Código Procesal Constitucional).

- La Procuraduría General del Estado (art. 65.4 del Código Procesal Constitucional).

- La Defensoría de la Niñez y la Adolescencia (art. 65.5 del Código Procesal Constitucional).

Respecto a la legitimación pasiva, la misma está relacionada a la competencia, así la SC 1386/2011-R sostiene respecto a la importancia de la legitimación pasiva y la posibilidad de la concesión de la acción de cumplimiento que: “...se traduce en que el juez o tribunal de garantías, ordenará el cumplimiento inmediato del deber omitido; resultando lógico que, el acatamiento de dicho fallo le corresponde a las autoridades o funcionarios públicos que tengan plena facultad para efectivizar la resolución dictada en sede constitucional. Y paralelamente a ello, también cumple el propósito de que el o los demandados -puestos en conocimiento del proceso constitucional seguido en su contra- comparezcan ante los tribunales de esta jurisdicción, otorgándoseles la oportunidad de ejercer su derecho a la defensa, oponiéndose al fundamento fáctico contenido en la demanda". En este sentido la acción de cumplimiento puede plantearse contra:

- Servidores públicos titulares de un deber impuesto por norma constitucional o de orden legal. Así en la SC 1534/2011-R se estableció que: “...la sola dimisión del funcionario público no excluye ni absuelve su responsabilidad por el deber que -en dicha calidad- hubiere incumplido... Del mismo modo, similar condición se advierte en relación al codemandado... quien fungiendo en el indicado cargo, incurrió en la misma negativa... así, se insiste en que la legitimación pasiva se determina por el solo incumplimiento del deber constitucional o legal, por parte de la autoridad (es) o funcionario (s) público, que -en dicha calidad-hubieren sido renuentes o remisos a su acatamiento".

En todo caso, debe demandarse a la autoridad que debe cumplir la norma y no a la que la emite, así la SC 1823/2011-R determinó falta de legitimación pasiva porque: "... los accionantes demandaron al Concejo Municipal, sin tomar en cuenta que si bien este ente normativo dicta la ordenanza municipal, empero, la autoridad encargada para su ejecución es el Ejecutivo Municipal...".

- No procede contra jueces y tribunales cuando ejercen actividad jurisdiccional.

- Autoridades Indígena Originario Campesinas (arts. 30-1 y 18 en concordancia con el art. 290-Il y art. $2^{\circ}$ de la CPE) salvo si ejercen competencia jurisdiccional.

- Particulares que prestan un servicio público (SC 1294/2011-R). Ej.: empresas privadas que realizan un servicio público o a particulares que ejercen competencias materialmente administrativas (art. 108-1 de la CPE). 


\section{Causales de improcedenCia}

Respecto a los supuestos de improcedencia de la acción de cumplimiento, se tiene que la norma a cumplirse debe ser manifestación expresa del legislador, sea constituyente u ordinario, es decir, no debe ser deducida o imaginada, por lo que tampoco es posible alegarse analogía en el cumplimiento de la norma ${ }^{19}$.

No procede contra actos de naturaleza privada, incluso emanen de autoridades públicas. En el derecho comparado, en el exp. 4260-2005-PC/TC del Tribunal Constitucional peruano, se sostuvo: "...conforme el petitorio de la demanda lo que en realidad pretende la demandante es el pago de la deuda que actualmente mantiene con ella la Municipalidad demandada, lo cual corresponde ser dilucidado en la vía ordinaria..." y que: "...la resolución cuyo cumplimiento solicita la demandante no se encuentra sujeta a los preceptos del Derecho Público o, lo que es lo mismo, no ha sido realizada en el ejercicio de la función administrativa. De modo que el origen de la obligación dineraria cuyo pago pretende la demandante no es el acto cuyo cumplimiento se solicita, sino más bien un contrato suscrito con la demandante, en donde la Administración no actúa ejerciendo sus potestades públicas administrativas".

No procede "Cuando sea viable la interposición de las acciones de Libertad, Protección de Privacidad o Popular" (art. 66.1 del Código Procesal Constitucional) y "En procesos o procedimientos propios de la administración, en los cuales se vulneren derecho y garantías constitucionales, tutelados por la Acción de amparo Constitucional" (art. 66.4 del Código Procesal Constitucional) debido a que las acciones mencionadas tienen como propósito principal la tutela de derechos subjetivos o de derechos colectivos, por lo que, sus ámbitos de protección son totalmente diferentes a los de la acción de cumplimiento conforme se desarrolló en el punto 3 del presente trabajo.

En congruencia, la SC 1325/2011-R estableció que no es posible aplicar la teoría de los actos libremente consentidos a la acción popular, porque: “...constituye una causal de improcedencia de la acción de amparo el hecho de que el individuo hubiera consentido libremente que sus derechos fundamentales y garantías constitucionales puedan ser lesionados o amenazados... En cambio, en la acción de cumplimiento no está involucrada básicamente la lesión de derechos ni garantías del individuo, sino el cumplimiento estricto de la Constitución y de la Ley, por lo que su obediencia, acatamiento y observancia son obligatorias por parte de todas las personas, órganos públicos e instituciones, conforme determinan los arts. 108 y 410 de la CPE. Por consiguiente, esa actitud de sumisión es de orden público, lo que significa que tanto la Constitución como la Ley son de cumplimiento incondicional, y es el orden público el que

${ }^{19}$ Confróntese Exp. № 1066-2004-AC/TC del Tribunal Constitucional peruano. 
actúa como límite a la autonomía de la voluntad, porque el interés general de la sociedad y del Estado se impone frente a los derechos del individuo. En consecuencia, en el ámbito de la acción de cumplimiento no puede alegarse la concurrencia de actos consentidos, y menos que operen como causal de improcedencia" lo que resulta lógico si se considera que el orden público se constituye en un límite de la autonomía de la voluntad.

No procede: "Cuando el accionante no haya reclamado previamente y de manera documentada a la autoridad accionada, el cumplimiento legal del deber omitido" (art. 66.2 del Código Procesal Constitucional), es decir, no se haya constituido en renuencia a la parte demandada, salvo se pretenda evitar un perjuicio grave e inminente cuyo resultado pueda ser irremediable.

No puede utilizarse la acción de cumplimiento: "Para el cumplimiento de sentencias judiciales que tengan autoridad de cosa juzgada" (art. 66.3 del Código Procesal Constitucional) y en su caso resoluciones administrativas con la calidad de firmes.

En general, no procede la acción de cumplimiento para pedir el cumplimiento de normas procesales, así la SC 258/2011-R, sostuvo que: "...la acción de cumplimiento no procede para exigir la realización de normas, y tampoco de resoluciones, dentro de los procesos judiciales, por cuanto, por una parte, dicha labor es propia del órgano jurisdiccional y, por otra, porque el cumplimiento de las normas puede ser exigido por los procedimientos o mecanismos previstos por las mismas leyes, dependiendo del tipo de proceso del que se trate..." entendimiento seguido por las SSCC 1294/2011-R, SC 1312/2011-R.

Ni procede "Contra la Asamblea Legislativa Plurinacional con la intención de exigir la aprobación de una ley" (art. 66.5 del Código Procesal Constitucional) en cuyo caso procede la acción de inconstitucionalidad por omisión. En efecto pues mientras que la acción de cumplimiento tiene como propósito hacer cumplir la norma la figura de inconstitucionalidad por omisión busca hacer legislar, es decir, debe diferenciarse entre la validez de la norma (objeto de la acción de inconstitucionalidad) y la eficacia de la norma (objeto de la acción de cumplimiento), así: "...la validez significa que la ley debe ser obedecida y aplicada; la eficacia quiere decir que la ley es, en verdad, obedecida y aplicada..."20.

Considerando que la acción de cumplimiento no busca la tutela de un derecho subjetivo ni el establecimiento de indemnización, es decir, trasciende el interés individual, puede plantearse mientras subsista la omisión del deber constitucional o de carácter legal.

${ }^{20}$ KeLSEN, Hans, Introducción a la teoría pura del Derecho, UNAM, Tercera edición, 2002, p. 50. En: http://biblio.juridicas.unam.mx/libros/libro.htm?l=1956 [visitado el 29/09/2013]. 
En este sentido, por regla general, la posibilidad de plantear acciones constitucionales, entre ellas la acción de cumplimiento, subsiste mientras exista una situación francamente contraria a la Constitución, así en la SC 1823/2011-R los accionantes alegaban ser propietarios de un inmueble respecto al cual una Ordenanza Municipal de 1999 disponía su expropiación y les prohibía por ende disponer del mismo, por lo que solicitaron al Tribunal Constitucional el cumplimiento de la referida Ordenanza Municipal, lo que dio lugar a una decisión denegatoria porque: "...si consideraban que su derecho a la propiedad estaba siendo lesionado como consecuencia de la no ejecución de la referida ordenanza municipal, bien pudieron recurrir al recurso ahora acción de amparo constitucional, que es una acción tutelar de carácter extraordinario tendiente a la protección de los derechos fundamentales..." y que: "...incluso para la interposición del recurso de amparo, considerado el medio idóneo para la protección inmediata de sus derechos, dejaron precluir; sin embargo, advertidos que la nueva Constitución Política del Estado, incorporó un nuevo instituto como es la acción de cumplimiento, recurren a la misma, a efectos de suplir su negligencia...".

Al respecto, independientemente a la acción constitucional que correspondía plantearse en el caso concreto, debe hacerse notar que si la omisión del deber legal persistía, podía plantearse la acción de cumplimiento independientemente el tiempo transcurrido y, por otra parte, que el plazo de seis meses de inmediatez para plantear la acción de amparo constitucional tampoco se aplica si la vulneración al derecho es permanente y continua.

Lo anterior, sin embargo, no significa que desde la constitución en renuencia de la parte demandada se tenga expedita de manera indefinida la posibilidad de plantear la acción de cumplimiento, porque la constitución en renuencia perdería uno de sus propósitos como es el de dar la oportunidad a la parte demandada de cumplir el deber omitido que por el transcurso del tiempo puede ser cambiada o verse la situación de incumplimiento modificada.

A contrario sensu, no procede la acción de cumplimiento si el deber omitido ya no existe, por ejemplo, si la norma que imponía el deber fue derogada o modificada o cuando el deber omitido sea de los que se agota con el primer acto.

En el caso último de modificación del deber omitido, para que opere la sustracción de la materia de una acción de cumplimiento en trámite debe la misma incidir necesariamente en la esencialidad del deber, es decir, transformándolo en otro totalmente diferente al que existía al momento de plantear la demanda de acción de cumplimiento, de lo contrario no se justificaría la sustracción de la materia.

No procede la acción de cumplimiento cuando existe otro mecanismo ordinario idóneo para alcanzar el mismo objetivo, así el art. 88 de la Ley del 
Tribunal Constitucional Plurinacional derogada establecía que: "procederá en caso de incumplimiento de disposiciones constitucionales o de la ley, siempre que no existan vías administrativas o judiciales para su eficaz protección", ello porque la justicia constitucional en general es residual.

Es improcedente una acción de cumplimiento cuando existe identidad de sujeto, objeto y causa con otra acción constitucional previamente planteada y existe ya al respecto cosa juzgada constitucional referida por el art. 203 de la Constitución Política del Estado, aspecto que impide un nuevo debate.

Por la naturaleza de la labor de la justicia constitucional, la acción de cumplimiento no procede ante situaciones complejas de interpretación de legalidad, así en la doctrina tenemos que: "Dado su carácter sumario y breve, no siendo el adecuado para discutir los contenidos de normas generales o de normas legales superpuestas que remitan a otras, y estas a su vez a otras, lo cual implica una actividad interpretativa compleja que en rigor debe llevarse a cabo a través de las vías procedimentales específicas" ${ }^{21}$.

La acción de cumplimiento no procede cuando exista un conflicto de competencias mientras el mismo no se haya tramitado, no procede para hacer cumplir contratos, incluso sean con entidades estatales, no procede para imponer sanciones, ni cuando se solicita dejar sin efecto una resolución, así en el derecho comparado el Tribunal Constitucional peruano en el exp. № No6- $^{\circ}$ 98-AC/TC sostuvo: "...En el caso de autos, la empresa demandante, a través de la presente acción de garantía, pretende, en esencia, que se deje sin efecto la Resolución de Alcaldía... Es decir, pretende impugnar un acto administrativo y no exigir su cumplimiento. Y, por lo tanto, la vía adecuada para accionar debió ser la de amparo y no la de cumplimiento...".

\section{Contenido de la demanda de ACCIÓN DE Cumplimiento}

Respecto a los requisitos esenciales de una demanda de acción de cumplimiento, en una interpretación "desde" la Constitución al art. 33 del Código Procesal Constitucional y considerando el propósito esencial de la acción de cumplimiento, es necesario lo siguiente:

El "Nombre, apellido y generales de quien interpone la acción o de su representante legal, acompañando en este último caso, la documentación que acredite su personería" (art. 33.1 del Código Procesal Constitucional).

El "Nombre y domicilio contra quien se dirige la acción, o los datos básicos para identificarla o identificarlo en el caso de que se conozca, el lugar donde pueda ser notificada o notificado" (art. 33.1 del Código Procesal Constitucional), en el marco de la acción de cumplimiento a la autoridad o persona particular

${ }^{21}$ Landa Arroyo, Cesar, Tribunal Constitucional y Estado Democrático, Editorial Palestra, 2007. 
que presta un servicio público renuente y titular del deber omitido (no la que hizo la norma sino la competente para cumplir).

Respecto a la "Relación de los hechos" constitutivos del incumplimiento (art. 33.4 del Código Procesal Constitucional), los mismos son necesarios esencialmente cuando se alega incumplimiento parcial o relativo de la norma constitucional o de rango legal.

La identificación de la norma o normas supuestamente incumplidas, pudiendo ejemplificarse cómo su incumplimiento afecta derechos, principios o valores constitucionales últimos que por la naturaleza y finalidad de la acción de cumplimiento no podría entenderse se constituyan en un requisito esencial o de fondo de la demanda, como lo determinó la SC 258/2011-R que por una parte sostuvo que la acción de cumplimiento otorga: "Tutela de manera indirecta derechos fundamentales y garantías constitucionales..." y a la vez contradictoriamente estableció como requisito de fondo: "Identificar los derechos o garantías que se consideren vulnerados directa o indirectamente; en ese sentido, no es requisito exigir que exista una relación de causalidad directa entre el incumplimiento del deber constitucional o legal omitido y el derecho o garantía supuestamente vulnerado".

En este marco, si bien la identificación de la norma -constitucional, ley formal o ley material-incumplida u omitida está relacionada con la constitución de renuencia -debe plantearse la acción de cumplimiento respecto a las normas con las cuales se constituyó en renuencia a la parte demandada- debe tenerse flexibilidad a momento admitir y considerar la acción de cumplimiento no sólo en atención al derecho de acceso a la justicia y al principio pro actione, sino porque esta acción constitucional no protege derechos subjetivos y el incumplimiento de la normatividad vigente es de interés público.

De tal manera que no tendría sentido alguno rechazar una demanda de acción de cumplimiento por la falta de precisión de la norma, cuando la misma, del contexto fáctico, es deducible o cuando es evidente el error en la parte accionante, máxime si se considera que la autoridad demandada no puede alegar ignorancia de la ley aplicable y los jueces y tribunales de garantías se encuentran vinculados al ordenamiento jurídico por el iura novit curia, de forma que lo importante es que la finalidad de la norma coincida con la demanda, pudiendo inclusive concederse la tutela ultra petita sin responsabilidad a la autoridad demandada.

Respecto al petitorio, en la SC 1412/2011-R el Tribunal Constitucional sostuvo que: "El accionante se presentó ante la 'Delegación' Distrital La Paz del Consejo de la Judicatura... para recoger el cheque 7719, pero sin embargo se le negó la entrega de ese documento, porque supuestamente el Juez Noveno de Partido en lo Civil y Comercial había ordenado el embargo del depósito judicial en cuestión, dentro del proceso coactivo civil seguido por el BCP contra 
el accionante... Empero, la referida acción de cumplimiento carece de los requisitos de fondo o contenido... es decir que el accionante no señaló ni precisó cuál la norma constitucional o legal general incumplida o inaplicada..." y en la SC 1017/2011-R que: "... los accionantes no han precisado cuál la renuencia del deber constitucional y legal omitido por las autoridades demandadas, señalando únicamente que el instructivo SH8377 ODECO 0783... emitido por la Superintendencia de Hidrocarburos, desconocía lo dispuesto en el Decreto Supremo 27.835 y Norma Boliviana 441 aprobada por Decreto Supremo 24721, sin identificar en estas disposiciones un deber claro, expreso y exigible a las autoridades regulatorias de hidrocarburos y que éstas hayan omitido; omisión que se hace más evidente si se considera el petitorio de la acción, en el que en vez de pedir el cumplimiento de determinado deber -que como se tiene explicado debió ser identificado de forma específica y no de forma genéricasolicitan la nulidad del instructivo SH8377 ODECO 0783... lo que evidencia la confusión de la acción interpuesta, cual si se tratara de una acción de amparo constitucional...".

La petición lógicamente es la de cumplimiento de la norma y, en definitiva, la precisión del resultado que la norma constitucional o de orden legal -ley en sentido formal o material- busca y debe alcanzar.

Eventualmente, la demanda puede contener una solicitud de medida cautelar (art. 33.6).

Finalmente, conjuntamente a la demanda, debe presentarse la prueba que acredite el incumplimiento o señalarse dónde se encuentra -piénsese, por ejemplo, en una inactividad derivada de mandatos de instrumentalización compleja-, y en especial la prueba de constitución de renuencia (art. 33.7 Código Procesal Constitucional).

\section{Procedimiento}

El art. 32.I del Código Procesal Constitucional establece que en general toda acción constitucional de este tipo: "Se presenta ante salas de turno en capitales de departamento o ante Juzgados Públicos de materia y fuera de capitales de departamento ante juzgados públicos o juzgados públicos mixtos" cuyo segundo parágrafo establece que: "El juzgado o tribunal competente será el del lugar en el que se haya producido la violación del derecho. Si en el lugar no hubiere autoridad judicial será competente la Jueza, Juez o Tribunal al que la parte pueda acceder por razones de cercanía territorial o mejores condiciones de transporte. Si la violación hubiere sido cometida fuera del lugar de residencia de la afectada o afectado, ésta o éste podrá presentar la acción, si lo estima pertinente ante el juzgado o tribunal competente por razón del domicilio" de donde puede deducirse que el planteamiento de la acción de cumplimiento debe efectuarse donde debía cumplirse o donde debía surtir efectos la norma constitucional 
o legal, por ejemplo, si se pide el cumplimiento de legislación municipal no resulta lógico que pueda plantearse la demanda en otro municipio.

El art. 31.I del Código Procesal Constitucional establece que: "La persona natural o jurídica que pruebe interés legítimo en una acción de defensa podrá presentarse ante la Jueza, Juez o Tribunal, que de estimarlo necesario, admitirá sus alegaciones en audiencia", en este sentido, considerando que la acción de cumplimiento no tutela derechos subjetivos y por la ingente cantidad de personas que pueden verse afectadas por la aplicación de una norma constitucional o legal corresponde admitir el amicus curiae y legitimación amplísima en este tipo de acciones constitucionales lo que concuerda con el art. 35.2 del Código Procesal Constitucional que impele al juez a ordenar: "...la notificación para la audiencia a terceros interesados que puedan ser afectados en sus derechos o que aporten mayores elementos de juicio, para dictarse resolución".

Si el juez o tribunal observa una causal de improcedencia debe resolverla inmediatamente, y si procede a efectuar observaciones a los requisitos de admisibilidad de la demanda conforme el art. 30 del Código Procesal Constitucional debe otorgarse el plazo de tres días a la parte accionante para que subsane, y en caso de rechazarse la demanda la parte procesal accionante cuenta con el plazo de tres días para impugnar la determinación a la Comisión de Admisión del Tribunal Constitucional Plurinacional.

Cuando del análisis de la demanda el juez o tribunal de garantías se percata de que debió plantearse amparo constitucional o acción popular, y siempre y cuando se cumpla los requisitos de la demanda que en realidad debió plantearse, debe de oficio "transmutar" la demanda y darle el trámite de acción popular o amparo constitucional.

Admitida la demanda debe señalarse audiencia, disponiendo la notificación personal o por cédula de la parte demandada (art. 35.1 del Código Procesal Constitucional), la citación a terceros interesados en su caso mediante edictos (art. 35.2 del Código Procesal Constitucional), puede señalar medidas cautelares (art. $9^{\circ}$ del Código Procesal Constitucional) y adoptar toda medida necesaria para la realización de la audiencia, como, por ejemplo, solicitar prueba o solicitar se remitan informes y normativa interna para determinar la competencia de las autoridades que deben cumplir norma.

"La parte accionada podrá contestar la Acción de Defensa o informar antes o durante la audiencia pública" (art. 35.3 del Código Procesal Constitucional), en este sentido, si la parte demandada considera ser incompetente para dar cumplimiento a la norma debe de oficio identificar al juez o tribunal de garantías a la autoridad titular del deber omitido y en su caso responsable del incumplimiento.

La celebración de la audiencia puede efectuarse incluso sin la presencia de las partes procesales (art. 36.2 del Código Procesal Constitucional) y constará 
en acta "...pudiendo utilizarse otros medios de registro, excepto en los casos prohibidos por Ley" (art. 36.1 del Código Procesal Constitucional) y concluidas las exposiciones de las partes (art. 134-II CPE) se emitirá la resolución correspondiente.

La resolución puede ser objeto de solicitud de aclaración, enmienda o complementación que debe resolverse en la audiencia si es verbal o en 24 horas si la solicitud es escrita (art. 36.9 del Código Procesal Constitucional) y en caso de concederse la tutela la orden de cumplimiento debe determinar con claridad la obligación incumplida, la autoridad titular de la obligación incumplida y competente para efectivizar el fallo, plazo justificado de acuerdo al caso concreto así el art. 67 del Código Procesal Constitucional establece que: "...sentencia establecerá el cumplimiento inmediato del deber omitido, o en su caso determinará un plazo perentorio para el cumplimiento de la norma..." y en su caso se dispondrá la calificación de costas procesales.

La decisión "... será ejecutada inmediatamente y sin observación..." (art. 134-V de la CPE), salvo se disponga una medida cautelar (art. 34 del Código Procesal Constitucional) independientemente de la remisión al Tribunal Constitucional Plurinacional para su correspondiente revisión (art. 134-IV de la CPE).

En sede del Tribunal Constitucional Plurinacional tras su registro (art. 41 del Código Procesal Constitucional) siendo posible la acumulación de causas (art. 6.I del Código Procesal Constitucional) posteriormente se sortea por la Comisión de Admisión (art. 42 del Código Procesal Constitucional) debiendo resolverse en el término de treinta días pudiéndose "1. Confirmar en todo o en parte la resolución de la Jueza, Juez o Tribunal de origen. 2. Revocar en todo o en parte la resolución de la Jueza, Juez o Tribunal de origen" (art. 44 del Código Procesal Constitucional).

\section{CONCLUSIONES}

La acción de cumplimiento ante la mala voluntad o negligencia de autoridades públicas tiene como objeto básico determinar si las normas de índole constitucional o legal -ley en sentido formal o material- fueron o no eficaces, es decir, que el objeto de esta acción constitucional no es la dar lugar a oír las excusas de autoridades que justifiquen el incumplimiento de las normas.

El resguardo del estado de derecho (art. $1^{\circ} \mathrm{CPE}$ ), la supremacía constitucional (art. 410-II de la CPE), el deber fundamental de: “...cumplir y hacer cumplir la Constitución y las leyes" (art. 108-1 de la CPE); los principios de igualdad, legalidad y seguridad jurídica justifican y fundamentan a la acción de cumplimiento.

La clasificación de las acciones constitucionales tiene una finalidad únicamente didáctica, en este sentido, la acción de cumplimiento tutela derechos al igual que puede tutelar principios o valores constitucionales en su dimensión 
objetiva, salvo el derecho subjetivo de asegurar y exigir la eficacia de las normas, máxime cuando el cumplimiento de la normativa se constituye en una condición esencial para el ejercicio de derechos subjetivos. Así no resulta lógico exigir como requisito de fondo o contenido en la demanda de acción de cumplimiento la precisión de derechos subjetivos como lo hace la SC 258/2011-R.

No existe un plazo para plantear la demanda de acción de cumplimiento, sino que la posibilidad de su interposición subsiste mientras la omisión del deber constitucional o de orden legal existe, aunque desde la constitución de la renuencia hasta el planteamiento de la demanda no debe transcurrir un término irrazonable que deje sin efecto la finalidad de la constitución en renuencia.

La raigambre histórica en Bolivia de la acción de amparo constitucional provocó que el legislador ordinario y la jurisprudencia constitucional haga del resto de acciones constitucionales -acción de protección de privacidad, acción de cumplimiento, acción popular-amparos constitucionales específicos, lo que no resulta lógico si se considera que el legislador constituyente les dio una configuración y especificidad propia, por lo que, procesalmente hablando, la existencia de la acción de cumplimiento dependerá sin duda alguna de la autonomía que llegue a adquirir frente al amparo constitucional y, asimismo, queda la pregunta de si algún día y respecto a Bolivia: “...podrá erradicarse de nuestras autoridades públicas, aquella perniciosa costumbre en virtud de la cual, las normas jurídicas se obedecen pero no se cumplen"22.

${ }^{22}$ Gaceta Constitucional Colombiana No 19. Expresiones de Álvaro Gómez Hurtado. En: http://www. elabedul.net/Documentos/Temas/Asamblea_Constituyente/Gaceta_019.pdf [visitado el 30/08/2012]. 